\title{
Some aspects about the spatial dependence index for variability of soil attributes
}

\section{Eduardo Lucas Ensslin dos $\operatorname{Santos}^{1} \odot$ Enio Júnior Seidel ${ }^{1^{*}} \odot$ Juliano de Bastos Pazini $^{2}$

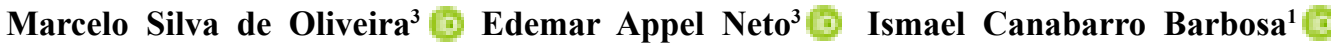

${ }^{1}$ Departamento de Estatística, Universidade Federal de Santa Maria (UFSM), 97105.900, Santa Maria, RS, Brasil. E-mail: enioseidel@gmail.com. ${ }^{*}$ Corresponding author.

${ }^{2}$ Departamento de Fitossanidade, Universidade Federal de Pelotas (UFPel), Capão do Leão, RS, Brasil.

${ }^{3}$ Departamento de Estatística, Universidade Federal de Lavras (UFLA), Lavras, MG, Brasil.

\begin{abstract}
The main purpose of this article was to evaluate the behavior and relationship of the range and components of SDI (Spatial Dependence Index) in general and in function of field factors such as soil types, type of attribute and soil layers. This evaluation was based on real data collected in national journals. It was noticed that the parameter range, in general and for different field factors, presented asymmetric positive behavior. The components of the SDI showed approximately symmetrical behavior. The SDI can capture the range behavior more intensely (the spatial variability behavior in the horizontal direction of the semivariogram), and, in a less intense way, the behavior of the contribution and sill parameters (the spatial dependence behavior in the vertical direction of the semivariogram). Thus, the SDI describes the behavior of spatial dependence of the total set of aspects of the semivariogram.

Key words: spatial dependence, geostatistics, semivariogram, field factors.
\end{abstract}

Alguns aspectos sobre o índice de dependência espacial para variabilidade de atributos do solo

RESUMO: $O$ objetivo deste artigo foi avaliar o comportamento e o relacionamento do alcance e dos componentes do IDE (Índice de Dependência Espacial) em geral e em função de fatores de campo, tais como tipos de solo, tipo de atributo e profundidades de solo. Esta avaliação foi baseada em dados reais coletados em periódicos nacionais. Foi observado que o parâmetro alcance, em geral, e para diferentes fatores de campo, apresentou comportamento de assimetria positiva. Os componentes do IDE apresentaram comportamento aproximadamente simétrico. O IDE consegue captar, de forma mais intensa, o comportamento do alcance (o comportamento da variabilidade espacial no sentido horizontal do semivariograma), e, de forma menos intensa, o comportamento dos parâmetros contribuição e patamar (o comportamento da dependência espacial no sentido vertical do semivariograma). Assim, o IDE descreve o comportamento de dependência espacial de toda a gama de aspectos do semivariograma.

Palavras-chave: dependência espacial, geostatística, semivariograma, fatores de campo.

The soil attributes, determinants of agricultural productivity and their impacts on the environment, vary at space and/or time (CAVALLINI et al., 2010). Usually, the evaluation of this variability is done using the experimental semivariogram and; consequently, of the estimation of the model parameters of the semivariogram, which, in most cases, are the nugget effect, the contribution, the sill and the range (SEIDEL \& OLIVEIRA, 2013, 2014).

The range has the capacity of describing the spatial variability in the horizontal direction of the semivariogram, and this parameter can be measured in meters, independently of the attribute under study. This parameter indicates the distance that the sampled points are correlated (VIEIRA et al., 1983; RODRIGUES et al., 2012; AQUINO et al., 2014). The nugget effect, the contribution and the sill allow the evaluation of the spatial variability in the vertical direction of the semivariogram, depending, however, on the unit of measure of the attribute under study, making a general evaluation directly based on its numerical values impossible. BIONDI et al. (1994) and CAMBARDELLA et al. (1994) proposed to relate these vertical parameters of 
the semivariogram to generate dimensionless spatial dependence measures.

Recently, SEIDEL \& OLIVEIRA (2014, 2016) proposed a dimensionless spatial dependence index (SDI) to evaluate the spatial variability contemplating all semivariogram parameters under spherical, exponential and Gaussian models adjustment. SEIDEL \& OLIVEIRA (2014) carried out theoretical and simulation studies that showed good performance of the SDI in the measurement of spatial variability.

However, a deeper assessment of the components of the SDI index still needs to be done. Thus, the objective of this article is to evaluate the behavior and the relationship of the range and the components of the SDI in general and in function of some field factors (different soil types, type of attribute and soil depths). According to CHERUBIN et al. (2014), several studies show how the spatial variability depends on field factors, such as soil type or type of attribute in study. ZANÃO JÚNIOR et al. (2010) comments that soil depths also influenced spatial variability. However, more field factors, such as relief type or land use and management, should be considered in future studies.

The data were obtained from 25 articles, published from 2006 to 2015 and made available on the Scielo Brazil portal, with application of Geostatistics in Soil attributes, used and cited in SEIDEL \& OLIVEIRA (2016). From the papers, the following information was collected for each attribute: model of semivariogram adjusted, estimated range (a), estimated nugget effect $\left(C_{0}\right)$, estimated contribution $\left(C_{1}\right)$, estimated sill $\left(C=C_{0}+C_{1}\right)$, maximum sample distance $(M D)$, soil type, type of attribute (chemical, physical or mineralogical) and soil layer (depth). In this way, it was possible to obtain the SDI and its two components: $\left(\frac{C_{1}}{C_{0}+C_{1}}\right)$ and $\left(\frac{a}{0.5 M D}\right)$. The mathematical expression of the SDI and its respective classification of the spatial dependence are detailed in SEIDEL \& OLIVEIRA (2016).

A total of 587 attributes were raised in the search, and in 275 of them (corresponding to $46.85 \%$ of the total) the spherical model was adjusted; in $123(20.95 \%)$ the exponential model was used; in $102(17.38 \%)$ attributes the Gaussian model was adjusted and; in $87(14.82 \%)$ the pure nugget effect model was used. MONTANARI et al. (2008) reported that several surveys of spatial variability of soils used prominently spherical and exponential models. As an estimation, it is possible to highlight the spherical model as one of greater use. This model is what predominates in studies in Soil Sciences (GREGO \& VIEIRA, 2005; GONTIJO et al., 2012). In addition, considering the exponential, Gaussian and spherical model adjustments (500 attributes), regardless of the type of attribute studied (whether chemical, physical or mineralogical), the spherical model is the predominate in semivariogram adjustments (54.37\% in chemical attributes, $53.82 \%$ in physical attributes, $64.44 \%$ in mineralogical attributes).

From the sampling of range values and the obtainment of the components of the SDI, statistical analyzes of this information were carried out, through descriptive measures. The Spearman $\frac{C_{1}}{C_{0}+C_{1}} \frac{a}{0.5 M D}$ correlations between range, and SDI were calculated and tested $(p<0.05)$. Data analysis procedures were performed in the software R (R CORE TEAM, 2016).

Sample distribution of the range is a positive asymmetry, with an asymmetry coefficient equal 2.12 and a median of the range equals to $39 \mathrm{~m}$ (Table 1). The same behavior of positive asymmetry is evident for the range in different semivariogram models (spherical, exponential and Gaussian), soil types, chemical and physical attributes and soil layers (Table 1).

Considering the median of the range as a comparative measure, the ultisol (median of $48.69 \mathrm{~m}$ ) has a higher value than the oxisol (median of $18.90 \mathrm{~m}$ ) (Table 1). This greater spatial continuity may be due to the shape of the landscape that the soil classes are inserted (CAMARGO et al., 2010, 2013; SILVA JUNIOR et al., 2012; RESENDE et al., 2014). MONTANARI et al. (2008) noticed higher values of range for chemical soil attributes in areas with linear pedoform (ultisol) compared to areas with convex pedoform (oxisol).

Another important observation, from table 1 , is that the range has higher median values for bottom soil layers. This can be explained by the fact that deeper layers have less spatial discontinuity of the soil attributes, since they are less susceptible to the effects of surface management, thus maintaining their original characteristics of homogeneity (LEÃO et al., 2007).

Chemical and physical attributes have higher median values to the range (median of $40.00 \mathrm{~m}$ and median of $38.00 \mathrm{~m}$, respectively) in comparison with 
Table 1 - Descriptive measures of the range (m), $\frac{a}{0.5 M D}$ (\#) and $\frac{C_{1}}{C_{0}+C_{1}}$ (\$), in general and in different semivariogram models, soil types, type of attribute and soil layers.

\begin{tabular}{|c|c|c|c|c|c|c|}
\hline Situation & Measure & Minimum & Median & Maximum & Mean $\pm \mathrm{SD}^{1}$ & $\mathrm{CA}^{2}$ \\
\hline \multirow{3}{*}{$\begin{array}{l}\text { General } \\
(n=500)\end{array}$} & Range (m) & 8.00 & 39.00 & 399.00 & $54.61 \pm 50.80$ & 2.12 \\
\hline & \# & 0.03 & 0.51 & 1.00 & $0.56 \pm 0.29$ & 0.19 \\
\hline & $\$$ & 0.20 & 0.67 & 1.00 & $0.67 \pm 0.20$ & 0.09 \\
\hline \multirow{3}{*}{$\begin{array}{l}\text { Exponential } \\
\text { model } \\
(n=123)\end{array}$} & Range (m) & 8.80 & 27.60 & 248.70 & $46.22 \pm 47.13$ & 2.37 \\
\hline & \# & 0.03 & 0.47 & 1.00 & $0.54 \pm 0.28$ & 0.31 \\
\hline & $\$$ & 0.34 & 0.69 & 1.00 & $0.70 \pm 0.17$ & 0.17 \\
\hline \multirow{3}{*}{$\begin{array}{l}\text { Gaussian } \\
\text { model } \\
(n=102)\end{array}$} & Range (m) & 10.00 & 20.48 & 240.00 & $41.98 \pm 42.11$ & 1.99 \\
\hline & \# & 0.08 & 0.33 & 1.00 & $0.44 \pm 0.32$ & 0.63 \\
\hline & $\$$ & 0.21 & 0.76 & 1.00 & $0.73 \pm 0.21$ & -0.34 \\
\hline \multirow{3}{*}{$\begin{array}{l}\text { Spherical } \\
\text { model } \\
(n=275)\end{array}$} & Range (m) & 8.00 & 47.60 & 399.00 & $63.05 \pm 53.82$ & 2.05 \\
\hline & \# & 0.07 & 0.60 & 1.00 & $0.62 \pm 0.27$ & 0.15 \\
\hline & $\$$ & 0.20 & 0.62 & 1.00 & $0.64 \pm 0.20$ & 0.26 \\
\hline \multirow{3}{*}{$\begin{array}{l}\text { Oxisol soil } \\
(\mathrm{n}=171)\end{array}$} & Range (m) & 8.00 & 18.90 & 399.00 & $40.73 \pm 53.40$ & 3.43 \\
\hline & \# & 0.03 & 0.36 & 1.00 & $0.46 \pm 0.32$ & 0.47 \\
\hline & $\$$ & 0.25 & 0.70 & 1.00 & $0.71 \pm 0.20$ & -0.01 \\
\hline \multirow{3}{*}{$\begin{array}{l}\text { Ultisol soil } \\
(\mathrm{n}=260)\end{array}$} & Range (m) & 12.90 & 48.69 & 248.70 & $64.39 \pm 50.06$ & 1.50 \\
\hline & $\#$ & 0.20 & 0.57 & 1.00 & $0.62 \pm 0.26$ & 0.28 \\
\hline & $\$$ & 0.20 & 0.63 & 1.00 & $0.63 \pm 0.19$ & 0.20 \\
\hline \multirow{3}{*}{$\begin{array}{l}\text { Other soils } \\
(n=69)\end{array}$} & Range (m) & 8.80 & 48.30 & 188.40 & $52.19 \pm 37.60$ & 1.07 \\
\hline & $\#$ & 0.18 & 0.55 & 1.00 & $0.60 \pm 0.27$ & 0.28 \\
\hline & $\$$ & 0.25 & 0.71 & 1.00 & $0.73 \pm 0.19$ & -0.05 \\
\hline \multirow{3}{*}{$\begin{array}{l}\text { Surface soil } \\
\text { layer }^{* *} \\
(n=342)\end{array}$} & Range (m) & 8.10 & 34.74 & 295.20 & $51.35 \pm 47.46$ & 2.03 \\
\hline & $\#$ & 0.03 & 0.50 & 1.00 & $0.55 \pm 0.28$ & 0.27 \\
\hline & $\$$ & 0.20 & 0.67 & 1.00 & $0.66 \pm 0.20$ & 0.06 \\
\hline \multirow{3}{*}{$\begin{array}{l}\text { Bottom soil } \\
\text { layer }^{* * *} \\
(n=158)\end{array}$} & Range (m) & 8.00 & 43.45 & 399.00 & $61.69 \pm 56.92$ & 2.14 \\
\hline & $\#$ & 0.03 & 0.54 & 1.00 & $0.59 \pm 0.31$ & 0.01 \\
\hline & $\$$ & 0.20 & 0.66 & 1.00 & $0.69 \pm 0.20$ & 0.14 \\
\hline \multirow{3}{*}{$\begin{array}{l}\text { Chemical } \\
\text { atribute } \\
(n=206)\end{array}$} & Range (m) & 8.00 & 40.00 & 399.00 & $59.49 \pm 60.07$ & 2.06 \\
\hline & \# & 0.03 & 0.47 & 1.00 & $0.51 \pm 0.33$ & 0.22 \\
\hline & $\$$ & 0.20 & 0.63 & 1.00 & $0.65 \pm 0.20$ & 0.06 \\
\hline \multirow{3}{*}{$\begin{array}{l}\text { Physical } \\
\text { atribute } \\
(n=249)\end{array}$} & Range (m) & 8.80 & 38.00 & 295.20 & $54.02 \pm 45.77$ & 1.62 \\
\hline & $\#$ & 0.18 & 0.56 & 1.00 & $0.60 \pm 0.26$ & 0.33 \\
\hline & $\$$ & 0.20 & 0.67 & 1.00 & $0.68 \pm 0.21$ & 0.12 \\
\hline \multirow{3}{*}{$\begin{array}{l}\text { Mineralogical } \\
\text { atribute } \\
(n=45)\end{array}$} & Range (m) & 16.60 & 30.50 & 70.15 & $35.58 \pm 13.30$ & 0.69 \\
\hline & $\#$ & 0.23 & 0.43 & 1.00 & $0.56 \pm 0.26$ & 0.62 \\
\hline & $\$$ & 0.36 & 0.68 & 1.00 & $0.69 \pm 0.13$ & 0.13 \\
\hline
\end{tabular}

${ }^{1}$ Standard deviation. ${ }^{2}$ Coefficient of asymmetry. ${ }^{* *}$ Surface soil layer $(0-0.1,0-0.15,0-0.2 \mathrm{~m}) .{ }^{* * *}$ Bottom soil layer $(0.1-0.2,0.15-0.3,0.2-$ 0.3, 0.2-0.4, 0.3-0.4, 0.4-0.6 m). $\mathrm{n}=$ number of model adjustments to semivariogram (in distinct soil attributes).

mineralogical attributes (median of $30.50 \mathrm{~m}$ ) (Table 1$)$. The value of the range influences the quality of the estimation (COSTA et al., 2014) and has application in the planning of samples (ZANÃO JÚNIOR et al., 2010). AQUINO et al. (2014) and OLIVEIRA et al. $(2015 \mathrm{a}, \mathrm{b})$ demonstrated the applicability of the range in the definition of sampling densities for future studies. 
As regards the $\frac{a}{0.5 M D}$, a slightly symmetrical behavior was observed, in general, with a median of 0.51 and an asymmetry coefficient of 0.19 (Table 1). Also, this component showed more median value for the spherical semivariogram model; Ultisol had a higher median value when compared to oxisol; Both soil depths have very close median values for this component; Physical attributes had a higher median value when compared to chemical and mineralogical attributes (Table 1).

The component $\frac{C_{1}}{C_{0}+C_{1}}$ showed an approximately symmetrical behavior, in general, with asymmetry coefficient equal 0.09 and median of 0.67 , and for the all semivariogram models, except for the Gaussian model that presented negative asymmetry, with a coefficient of asymmetry equal -0.34 (Table 1 ).

Considering the different types of soil, it can be seen from table 1 that $\frac{C_{1}}{C_{0}+C_{1}}$ has a higher median value in the oxisol $(0.70)$ than in the ultisol (0.63).

Another emphasis was that the median values of $\frac{C_{1}}{C_{0}+C_{1}}$ did not vary for different soil depths. This result differs from that obtained by GREGO \& VIEIRA (2005) and ZANÃO JÚNIOR et al. (2010) who observed differences in spatial dependence for different soil depths. The component $\frac{C_{1}}{C_{0}+C_{1}}$ has higher median values in the all the types of attributes (Table 1).

Amplitud of the component $\frac{C_{1}}{C_{0}+C_{1}}$, in general, ranged from 0.20 to 1.00 , showing that this component does not tend to present low values in practice. Based on this, taking into account that the $\frac{C_{1}}{C_{0}+C_{1}}$ also generates the measure proposed in BIONDI et al. (1994), which is used together with the classification of CAMBARDELLA et al. (1994), it tends to consider more attributes as having greater spatial dependence (that is, with a degree of spatial dependence tending to be stronger) than would occur in reality. In addition, it is emphasized that, in the Gaussian model, there is a greater tendency of strong classifications of spatial dependence, when compared with the other two semivariogram models.

Based on table 2, it can be shown that, in general and for different field factors, the correlations between the range and the SDI index are moderately or strongly positive, and all significant $(p<0.05)$. The SDI index has a positive asymmetric sampling distribution (SEIDEL \& OLIVEIRA, 2016) similar to what occurs with the range, explaining results obtained by the correlations. The correlations between

$a$

$0.5 M D$

and SDI are all strongly positive, and all significant $(\mathrm{p}<0.05)$. However, the correlations between $\frac{C_{1}}{C_{0}+C_{1}}$ and SDI are weak or moderate (and most of the time are positive).

Furthermore, it can be seen from table 2 that only weak or moderate and negative correlations occurred between $\frac{C_{1}}{C_{0}+C_{1}}$ and range. This means that where we have greater values of the range it could occur lower values of $C_{1}$

$\overline{C_{0}+C_{1}}$ and vice versa, showing that using only the range (horizontal spatial dependence of the semivariogram) or using only $\frac{C_{1}}{C_{0}+C_{1}}$ (vertical spatial dependence of the semivariogram) is not the most adequate method of describing the spatial variability of attributes.

Results obtained from the correlations indicated that the SDI is able to capture, in an intense way, the behavior of the range and the $\frac{a}{0.5 M D}$ when evaluating the spatial dependence, evidencing also the behavior in the horizontal sense of the semivariogram. This is an important feature of the SDI index, which differentiates it from other indexes in the literature, since according to FERRAZ et al. (2012) the range has a considerable role in determining the limit of spatial dependence. In addition, the SDI also succeeds in capturing, in a less intense way, the behavior of $\frac{C_{1}}{C_{0}+C_{1}}$ , minimally describing the vertical behavior of the semivariogram. In general, the SDI attempts to describe spatial dependence by capturing both the aspect described by the range (horizontal parameter of semivariogram) and the aspect described by nugget effect, contribution and sill (vertical parameters of semivariogram). 
Table 2 - Correlations (Spearman) between SDI, range (m), $\frac{a}{0.5 M D}$ (\#) and $\frac{C_{1}}{C_{0}+C_{1}}$ (\$), in general and in different semivariogram models, soil types, type of attribute and soil layers.

\begin{tabular}{|c|c|c|c|c|}
\hline Situation & Measure & SDI & Range (m) & \# \\
\hline \multirow{3}{*}{$\begin{array}{l}\text { General } \\
(n=500)\end{array}$} & Range (m) & $0.5606^{*}$ & & \\
\hline & $\#$ & $0.8327^{*}$ & $0.7841^{*}$ & \\
\hline & $\$$ & $0.2582^{*}$ & $-0.3416^{*}$ & $-0.2235^{*}$ \\
\hline \multirow{3}{*}{$\begin{array}{l}\text { Exponential } \\
\text { model } \\
(n=123)\end{array}$} & Range (m) & $0.5890^{*}$ & & \\
\hline & \# & $0.8925^{*}$ & $0.7456^{*}$ & \\
\hline & $\$$ & $0.2542^{*}$ & $-0.2616^{*}$ & $-0.1625^{\mathrm{ns}}$ \\
\hline \multirow{3}{*}{$\begin{array}{l}\text { Gaussian } \\
\text { model } \\
(n=102)\end{array}$} & Range (m) & $0.6296^{*}$ & & \\
\hline & $\#$ & $0.9177^{*}$ & $0.7628^{*}$ & \\
\hline & $\$$ & $-0.0879^{\mathrm{ns}}$ & $-0.5052^{*}$ & $-0.4235^{*}$ \\
\hline \multirow{3}{*}{$\begin{array}{l}\text { Spherical } \\
\text { model } \\
(n=275)\end{array}$} & Range (m) & $0.5637^{*}$ & & \\
\hline & $\#$ & $0.8229^{*}$ & $0.7915^{*}$ & \\
\hline & $\$$ & $0.4906^{*}$ & $-0.1740^{*}$ & $-0.0491^{\mathrm{ns}}$ \\
\hline \multirow{3}{*}{$\begin{array}{l}\text { Oxisol soil } \\
(\mathrm{n}=171)\end{array}$} & Range (m) & $0.6198^{*}$ & & \\
\hline & \# & $0.8872^{*}$ & $0.7923^{*}$ & \\
\hline & $\$$ & $-0.0689^{\text {ns }}$ & $-0.4564^{*}$ & $-0.4371^{*}$ \\
\hline \multirow{3}{*}{$\begin{array}{l}\text { Ultisol soil } \\
(\mathrm{n}=260)\end{array}$} & Range (m) & $0.4276^{*}$ & & \\
\hline & $\#$ & $0.8237^{*}$ & $0.6772^{*}$ & \\
\hline & $\$$ & $0.5415^{*}$ & $-0.2415^{*}$ & $0.0256^{\mathrm{ns}}$ \\
\hline \multirow{3}{*}{$\begin{array}{l}\text { Other soils } \\
(\mathrm{n}=69)\end{array}$} & Range (m) & $0.7465^{*}$ & & \\
\hline & $\#$ & $0.7816^{*}$ & $0.8748 *$ & \\
\hline & $\$$ & $0.3971^{*}$ & $-0.0842^{\mathrm{ns}}$ & $-0.1063^{\mathrm{ns}}$ \\
\hline \multirow{3}{*}{$\begin{array}{l}\text { Surface soil } \\
\text { layer }^{* *} \\
(n=342)\end{array}$} & Range (m) & $0.5277^{*}$ & & \\
\hline & \# & $0.8203^{*}$ & $0.7670^{*}$ & \\
\hline & $\$$ & $0.2479^{*}$ & $-0.3519^{*}$ & $-0.2464^{*}$ \\
\hline \multirow{3}{*}{$\begin{array}{l}\text { Bottom soil } \\
\text { layer }^{* * *} \\
(n=158)\end{array}$} & Range (m) & $0.6172^{*}$ & & \\
\hline & \# & $0.8430^{*}$ & $0.8084^{*}$ & \\
\hline & $\$$ & $0.2825^{*}$ & $-0.3262^{*}$ & $-0.1795^{*}$ \\
\hline \multirow{3}{*}{$\begin{array}{l}\text { Chemical } \\
\text { attribute } \\
(n=206)\end{array}$} & Range (m) & $0.5348^{*}$ & & \\
\hline & \# & $0.8763^{*}$ & $0.7662^{*}$ & \\
\hline & $\$$ & $0.1074^{\mathrm{ns}}$ & $-0.4745^{*}$ & $-0.3047^{*}$ \\
\hline \multirow{3}{*}{$\begin{array}{l}\text { Physical } \\
\text { attribute } \\
(n=249)\end{array}$} & Range (m) & $0.5932^{*}$ & & \\
\hline & \# & $0.7729^{*}$ & $0.8043^{*}$ & \\
\hline & $\$$ & $0.3956^{*}$ & $-0.2024^{*}$ & $-0.1792^{*}$ \\
\hline \multirow{3}{*}{$\begin{array}{l}\text { Mineralogical } \\
\text { attribute } \\
(\mathrm{n}=45)\end{array}$} & Range (m) & $0.8976^{*}$ & & \\
\hline & $\#$ & $0.9211^{*}$ & $0.9766^{*}$ & \\
\hline & $\$$ & $-0.0582^{\mathrm{ns}}$ & $-0.3675^{*}$ & $-0.3222^{*}$ \\
\hline
\end{tabular}

${ }^{*}$ Significant Spearman correlation $(\mathrm{p}<0.05) .{ }^{\mathrm{n} s}$ Non-significant Spearman correlation. ${ }^{* *}$ Surface soil layer $(0-0.1,0-0.15,0-0.2 \mathrm{~m}) .{ }^{* * *}$ Bottom soil layer $(0.1-0.2,0.15-0.3,0.2-0.3,0.2-0.4,0.3-0.4,0.4-0.6 \mathrm{~m}) . \mathrm{n}=$ number of model adjustments to semivariogram (in distinct soil attributes). 


\section{CONFLICTS OF INTEREST}

The authors declare no conflict of interest.

\section{REFERENCES}

AQUINO, R.E. et al. Geostatistics in assessment of physical properties in a latossolo (oxisol) under native forest and grassland in Manicoré, Amazonas, Brazil. Revista Brasileira de Ciência do Solo, v.38, p.397-406, 2014. Available from: $<$ http://www.scielo.br/pdf/rbcs/v38n2/04.pdf $>$. Accessed: Jul. 18, 2017. doi: 10.1590/S0100-06832014000200004.

BIONDI, F. et al. Geostatistically modeling stem size and increment in an old-growth forest. Canadian Journal of Forest Research, v.24, p.1354-1368, 1994.

CAMARGO, L.A. et al. Spatial variability of physical attributes of an alfisol under different hillslope curvatures. Revista Brasileira de Ciência do Solo, v.34, p.617-630, 2010. Available from: $<$ http://www.scielo.br/scielo.php?script $=$ sci arttext\&pid $=$ S0100-06832010000300003 $>$. Accessed: Jul. 18, 2017. doi: 10.1590/S0100-06832010000300003.

CAMARGO, L.A. et al. Mineralogy of the clay fraction of Alfisols in two slope curvatures: III - spatial variability. Revista Brasileira de Ciência do Solo, v.37, p.295-306, 2013. Available from: <http://www.scielo.br/pdf/rbcs/v37n2/ a01v37n2.pdf>. Accessed: Jul. 18, 2017. doi: 10.1590/S010006832013000200001 .

CAMBARDELLA, C.A. et al. Field-scale variability of soil properties in Central Iowa soils. Soil Science Society of America Journal, v.58, p.1501-1511, 1994. Available from: $<$ http://dl.sciencesocieties.org/publications/sssaj/abstracts/58/5/ SS0580051501>. Accessed: Jun. 10, 2017. doi: 10.2136/sssaj199 4.03615995005800050033x.

CAVALLINI, M.C. et al. Relationships between yield of Brachiaria brizantha and physical properties of a savannah oxisol. Revista Brasileira de Ciência do Solo, v.34, p.10071015, 2010. Available from: <http://www.scielo.br/pdf/rbcs/ v34n4/01.pdf $>$. Accessed: Jul. 20, 2017. doi: 10.1590/S010006832010000400001 .

CHERUBIN, M.R. et al. Efficiency of sampling grids used in the characterization of phosphorus and potassium. Ciência Rural, v.44, p.425-432, 2014. Available from: <http://www. scielo.br/pdf/cr/v44n3/a6414cr2013-0771.pdf>. Accessed: Jul. 18, 2017. doi: 10.1590/S0103-84782014000300007.

COSTA, N.R. et al. Orange yield correlated with soil chemical attributes aiming specific management zones. Pesquisa Agropecuária Tropical, v.44, p.391-398, 2014. Available from: $<$ http://www.scielo.br/pdf/pat/v44n4/v44n4a01.pdf $>$. Accessed: Jul. 18, 2017. doi: 10.1590/S1983-40632014000400001.

FERRAZ, G.A.S. et al. Spatial and temporal variability of phosphorus, potassium and of the yield of a coffee field. Engenharia Agrícola, v.32, p.140-150, 2012. Available from: $<$ http://www.scielo.br/pdf/eagri/v32n1/15.pdf $>$. Accessed: Jul. 15, 2017. doi: 10.1590/S0100-69162012000100015.

GONTIJO, I. et al. Variability and spatial correlation among micronutrientes and organic matter and yield of black pepper.
Revista Brasileira de Ciência do Solo, v.36, p.1093-1102, 2012. Available from: <http://www.scielo.br/pdf/rbcs/ v36n4/04.pdf>. Accessed: Jul. 18, 2017. doi: 10.1590/S010006832012000400004 .

GREGO, C.R.; VIEIRA, S.R. Spatial variability of soil physical properties on an experimental plot. Revista Brasileira de Ciência do Solo, v.29, p.169-177, 2005. Available from: <http://www.scielo.br/pdf/rbcs/ v29n2/24153.pdf $>$. Accessed: Jul. 18, 2017. doi: 10.1590/ S0100-06832005000200002.

LEÃO, A.B. et al. Spatial variability of phosphorus in soil from irrigated perimeter Engenheiro Arcoverde, PB. Revista Ciência Agronômica, v.38, p.1-6, 2007.

MONTANARI, R. et al. Spatial variability of chemical attributes in latosol and argisol. Ciência Rural, v.38, p.12661272, 2008. Available from: <http://www.scielo.br/pdf/cr/ v38n5/a10v38n5.pdf>. Accessed: Jul. 18, 2017. doi: 10.1590/ S0103-84782008000500010.

OLIVEIRA, I.A. et al. Spatial variability and sampling density of magnetic susceptibility and soil properties in ultisols of the Manicoré region, AM, Brazil. Revista Brasileira de Ciência do Solo, v.39, p.668-681, 2015a. Available from: <http://www.scielo.br/pdf/rbcs/v39n3/01000683-rbcs-39-3-0668.pdf $>$. Accessed: Jul. 18, 2017. doi: $10.1590 / 01000683$ rbcs20140496.

OLIVEIRA, I.A. et al. Use of scaled semivariograms in the planning sample of soil chemical properties in Southern Amazonas, Brazil. Revista Brasileira de Ciência do Solo, v.39, p.31-39, 2015b. Available from: <http://www.scielo.br/ pdf/rbcs/v39n1/0100-0683-rbcs-39-1-0031.pdf>. Accessed: Jul. 18, 2017. doi: 10.1590/01000683rbcs20150525.

R CORE TEAM. R: A language and environment for statistical computing. Vienna: R Foundation for Statistical Computing, 2016. Available from: <http://www.R-project.org/>. Accessed: Jul. 18, 2017.

RESENDE, J.M.A et al. Spatial variability of the properties of cohesive soils from eastern Maranhão, Brazil. Revista Brasileira de Ciência do Solo, v.38, p.1077-1090, 2014. Available from: <http://www.scielo.br/pdf/rbcs/v38n4/04. pdf>. Accessed: Jul. 15, 2017. doi: 10.1590/S010006832014000400004 .

RODRIGUES, M.S. et al. Spatial relationships between soil attributes and corn yield in no-tillage system. Revista Brasileira de Ciência do Solo, v.36, p.599-609, 2012. Available from: <http://www.scielo.br/pdf/rbcs/v36n2/ a29v36n2.pdf $>$. Accessed: Jul. 18, 2017. doi: 10.1590/S010006832012000200029 .

SEIDEL, E.J.; OLIVEIRA, M.S. Proposal of a generalization for exponential and Gaussian semivariogram models. Semina: Ciências Exatas e Tecnológicas, v.34, p.125-132, 2013. Available from: <http://www.uel.br/revistas/uel/index.php/ semexatas/article/view/14114/13258>. Accessed: Jul. 18, 2017. doi: 10.5433/1679-0375.2013v34n1p125.

SEIDEL, E.J.; OLIVEIRA, M.S. New geostatistical index for measuring spatial dependence. Revista Brasileira de Ciência do Solo, v.38, p.699-705, 2014. Available from: <http://www. 
scielo.br/pdf/rbcs/v38n3/02.pdf>. Accessed: Jun. 10, 2017. doi: 10.1590/S0100-06832014000300002.

SEIDEL, E.J.; OLIVEIRA, M.S. A classification for a geostatistical index of spatial dependence. Revista Brasileira de Ciência do Solo, v.40, e0160007, 2016. Available from: $\quad<$ http://www.scielo.br/pdf/rbcs/v40/1806-9657-rbcs40-e0160007.pdf>. Accessed: Jul. 18, 2017. Epub. Dec. 15, 2016. doi: $10.1590 / 18069657 \mathrm{rbcs} 20160007$.

SILVA JUNIOR, J.F. et al. Geostatistical simulation for the spatial characterization of iron oxides in different landforms. Revista Brasileira de Ciência do Solo, v.36, p.1690-
1703, 2012. Available from: <http://www.scielo.br/pdf/rbcs/ v36n6/03.pdf>. Accessed: Jul. 18, 2017. doi: 10.1590/S010006832012000600003.

VIEIRA, S.R. et al. Geostatistical theory and application to variability of some agronomical properties. Hilgardia, v.51, p.1-75, 1983.

ZANÃO JÚNIOR, L.A. etal. Spatial variability of macronutrient contents in untilled oxisols. Revista Brasileira de Ciência do Solo, v.34, p.389-400, 2010. Available from: <http://www. scielo.br/pdf/rbcs/v34n2/v34n2a12.pdf >. Accessed: Jul. 18, 2017. doi: 10.1590/S0100-06832010000200012. 